\title{
Metastatic Minimally Invasive (Encapsulated) Follicular and Hurthle Cell Thyroid Carcinoma: A Study of 34 Patients
}

Neal S. Goldstein, M.D., Peter Czako, M.D., James S. Neill, M.D.

Departments of Anatomic Pathology (NSG, JSN) and General Surgery (PC), William Beaumont Hospital, Royal Oak, Michigan

Most studies that have examined minimally invasive, encapsulated, follicular carcinoma (FC) or Hurthle cell carcinomas (HCs) have contained only a few metastatic neoplasms. We studied 34 patients with a single, minimally invasive, metastatic FC or HC and compared them with 38 patients with similar, nonmetastatic FCs or HCs. The numbers of incomplete capsular penetration (neoplasm into but not through the capsule), complete capsular penetration (neoplasm through the capsule), and vascular invasion foci were quantified. The median number (three), range, and distribution of complete capsular penetration and vascular invasion foci were similar in the nonmetastatic and metastatic carcinomas. All of the metastatic FCs and HCs had at least one vascular invasion or complete capsular penetration focus. Sixty-two percent of the metastatic carcinomas had two to four complete capsular penetration foci, and $60 \%$ had two to four vascular invasion foci. Two metastatic neoplasms had incomplete capsular penetration but had one and two vascular invasion foci, respectively. One tumor had no vascular invasion but had four complete capsular penetration foci. No metastatic neoplasms had incomplete capsular penetration only. There were no differences in the number of vascular invasion or complete capsular penetration foci between metastatic and nonmetastatic FCs and HCs and between metastatic FCs and HCs. Most metastatic neoplasms had vascular space invasion and complete capsular penetration. The number of complete capsular penetration or vascular invasion foci was not associated with the initial site of metastasis

Copyright () 2000 by The United States and Canadian Academy of Pathology, Inc.

VOL. 13, NO. 2, P. 123, 2000 Printed in the U.S.A.

Date of acceptance: August 24, 1999.

Address reprint requests to: Neal S. Goldstein, M.D., Department of Anatomic Pathology, William Beaumont Hospital, 3601 West 13 Mile Road, Royal Oak, MI 48073; e-mail: ngoldstein@beaumont.edu; fax: 248-5519054 . or the interval between the surgery and the metastasis.

KEY WORDS: Capsular invasion, Encapsulated, Follicular carcinoma, Hurthle cell carcinoma, Metastases, Thyroid, Vascular invasion.

Mod Pathol 2000;13(2):123-130

There are two major types of intrathyroidal, low grade follicular carcinomas (FCs) and Hurthle cell carcinomas (HCs): widely invasive and minimally invasive (1-12). The latter type forms a solitary lesion in the thyroid and is almost always encapsulated. Extratumoral capsular extension, if present, is usually only several millimeters beyond the outer edges of the capsule.

The histologic features of vascular space invasion and capsular penetration as criteria for distinguishing follicular adenoma from minimally invasive carcinoma were first noted by Graham (2) in 1914 (Case 11074). Graham $(2,3)$ and Coller (4) formally established these features as criteria of malignancy in the early 1920s, and Warren (5) confirmed them in the early 1930s. Studies on the histopathologic criteria of minimally invasive, encapsulated HCs concluded that the histologic criteria for carcinoma in the minimally invasive HCs are the same as for FCs $(10,13-24)$.

The focus of this large body of studies has been on identifying the histologic features that predict for metastases or soft-tissue recurrences. One limitation of most of these studies is that the number of patients who develop metastases is few. A large number of metastatic noninvasive or minimally invasive neoplasms have been available only to a few authors. We identified 58 studies, other than case reports, that reported the number of patients with recurrent or metastatic intrathyroidal, minimally invasive FCs or HCs. Fourteen percent of these studies had no patients who developed a metastasis or soft-tissue neck recurrence, and $42 \%$ of the studies had five or fewer patients. There have been 
several studies that have addressed the range of pathologic features in metastatic minimally invasive FCs and HCs $(21,25-32)$.

We studied 34 patients who developed metastases or soft-tissue recurrences from a solitary, intrathyroidal, minimally invasive, encapsulated thyroid FC or HC. We compared them with 38 nonmetastatic, histologically identical FCs and HCs and explored associations between the follicular and Hurthle cell morphology.

\section{MATERIALS AND METHODS}

The William Beaumont Tumor Registry and Anatomic Pathology files were searched from January 1972 through October 1998 and June 1955 through October 1998, respectively, for patients with thyroid FC or HC or follicular and Hurthle cell lesions (adenomas or carcinomas of all grades). Patients were excluded from the search results if they had the following: thyroid adenomas without metastases; diffusely invasive FC or HC; extrathyroidal extension; multiple carcinomas; or insular, trabecular, medullary, anaplastic, or follicular variant of papillary carcinomas. All patients included in the study had follow-up information, including the time and location of the development of a metastasis or softtissue neck recurrence that was provided by the William Beaumont Tumor Registry. This registry tracks all patients with a malignancy treated at William Beaumont Hospital and records subsequent hospital, clinic, and William Beaumont Hospitalassociated primary medical physician visits. There was insufficient follow-up information after a patient's local metastasis or soft-tissue recurrence developed to determine the efficacy of various therapeutic efforts.

The control cases were selected from a pool of patients who had a single, nonmetastatic, encapsulated FC or HC and that were identified from our files during the time period of June 1955 through October 1998. The morphology of these neoplasms were identical to the metastatic neoplasms. All neoplasms had at least one focus of complete capsular penetration or vascular space invasion. Consecutive nonmetastatic cases equal to the number of metastatic cases from that decade plus an additional nonmetastatic case were selected for the study. This totaled 38 nonmetastatic FCs and HCs. Twenty-seven patients were female. Thirty-five patients were treated with complete thyroidectomy.

All 34 patients with metastatic FCs or HCs and 38 patients with nonmetastatic FCs or HCs had a single, grossly encapsulated carcinoma that was confined to the thyroid. Three patients from the 1960s were initially diagnosed as having an adenoma that subsequently metastasized.
The following features of the thyroid specimen were evaluated:

1. Maximum dimension of the carcinoma

2. Number of blocks submitted from the carcinoma

3. Number of slides made from the carcinoma blocks

4. Number of foci of complete capsular penetration, defined as tumor extension completely through the capsule. The criteria for complete capsular penetration are those defined by Lang et al. (26) and Franssila et al. (29) (Fig. 1). Complete capsular penetration was considered present only when there was total penetration of the tumor capsule by neoplastic tissue so that there was contact between tumor tissue and adjacent thyroid tissue. A thin pseudocapsule around the leading edge of the invasive focus was occasionally observed. Sharp projections of thyroid neoplasm that extended into but not through the capsule were not complete capsular penetration (33).

5 . Number of foci of incomplete capsular penetration, defined as carcinomatous extension into but not through the capsule (Fig. 2) (26, 29). Incomplete capsular penetration included irregular nests or fingers of tumor cells within the tumor capsule, beyond the outer circumferential edge of most of the neoplasm (27). It also included the lesions described as smoothly contoured, discrete, often almondshaped tumor islands within but not through the tumor capsule (33).

6. Number of vascular invasion foci subjacent to, in, or beyond the tumor capsule (Figs. 3 and 4) $(27,29,33)$. The most common pattern of vascular invasion was subendothelial tumor cell clusters or sheets that often formed polypoid projections into vessel lumina (33). Other patterns of vascular invasion included polypoid

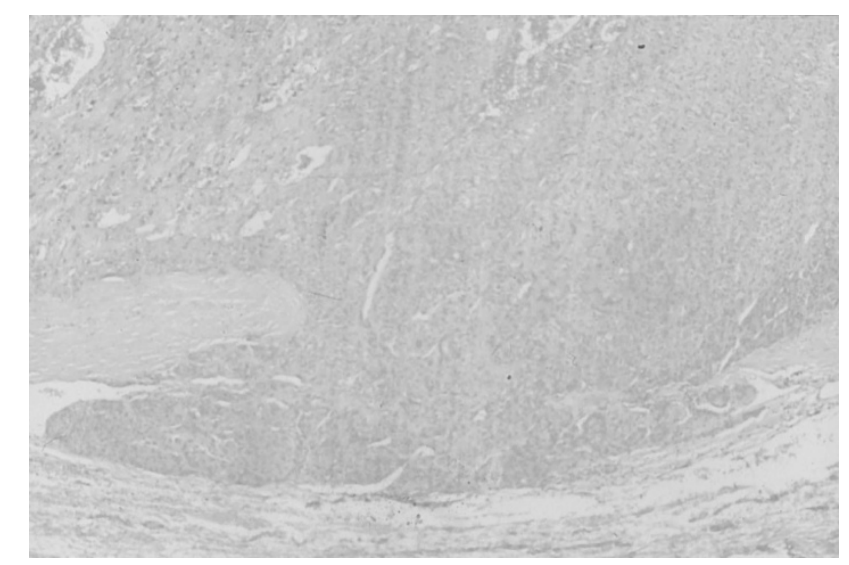

FIGURE 1. Complete capsular penetration. A tongue of follicular carcinoma has extended through the capsule of the neoplasm (hematoxylin and eosin, $76.8 \times$ ). 


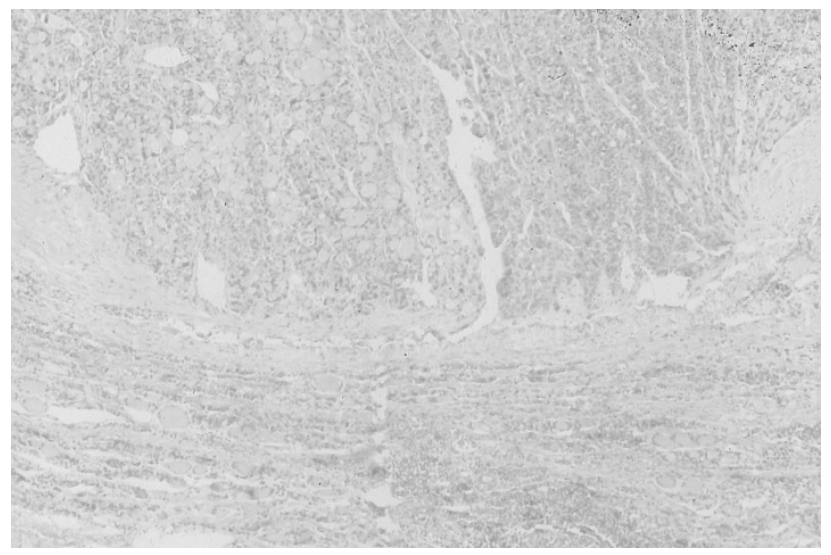

FIGURE 2. Incomplete capsular penetration by follicular carcinoma that extends into but not through the neoplasm's capsule. A thin rim of capsule remains between the front edge of the neoplasm and the adjacent thyroid parenchyma (hematoxylin and eosin, $76.8 \times$ ).

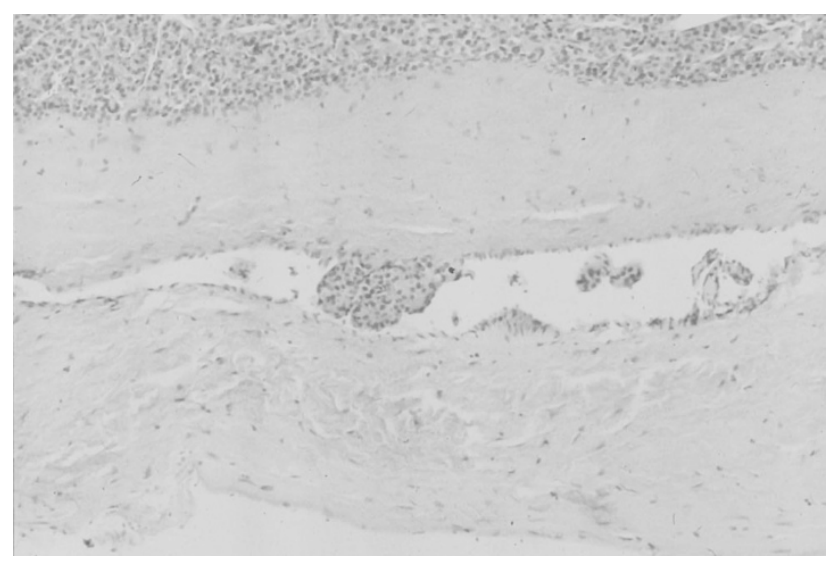

FIGURE 3. Vascular space invasion by follicular carcinoma in a vein immediately outside the neoplasm's capsule (hematoxylin and eosin, $76.8 \times)$.

tumor thrombi or large clusters of tumor cells that protruded into a large or moderate-sized vessel. Small tumor nests that slightly bulged into small, thin-walled vessels were not regarded as vascular invasion $(27,29)$. The tumor thrombi were usually covered by an endothelial layer. Smoothly outlined tumor thrombi that bulged into large veins that were not covered by endothelial layer were also considered as vascular invasion $(27,29)$. Tumor thrombus attachment to a vessel wall was not a prerequisite of vascular invasion $(27,29)$. Observing the actual point of vascular invasion into the vessel wall was also not required to diagnose vascular invasion $(1,27,29)$. Elastic stains were not used to diagnose vascular space invasion (29).

7. Hurthle or follicular subtype. Hurthle cell carcinoma was defined as having $75 \%$ or more of the neoplastic cells be of Hurthle cell type (15). One patient had a mixture of Hurthle cells and clear cells. Electron microscopy identified nu-

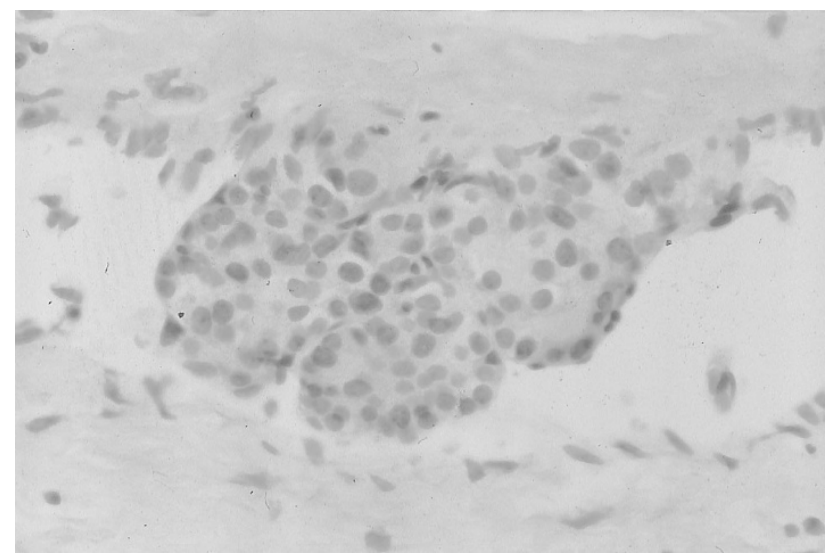

FIGURE 4. Vascular space invasion, higher magnification of Figure 3 The carcinoma embolus is attached to the vessel wall. There is a thin endothelium covering the embolus in the right half of the photograph (hematoxylin and eosin, 576×).

merous mitochondria in the clear cells, and it was classified as an HC (34).

The amount of incomplete and complete capsular penetration and vascular invasion was scored independently by two of the authors (NSG and JSN), and the mean value for each case was used in the final analyses. Also recorded for each patient were the date of surgery, age at the time of surgery, interval between the thyroid surgery and when clinical identification of the thyroid neoplasm metastasis or soft-tissue neck recurrence was detected, and location of the initial metastasis or soft-tissue neck recurrence. Fisher's exact $t$ test was used for statistical analyses.

\section{RESULTS}

\section{Clinical Information}

Twenty-seven of the 34 patients (79\%) who developed metastases were female. Thirty patients were treated by total thyroidectomy or lobectomy followed by contralateral completion lobectomy. The other four patients, who were operated on before 1966, underwent only a lobectomy. Three of these patients initially were diagnosed as having an adenoma. The mean and median follow-up periods were 11.5 and 6.1 years, respectively (range, 140 days to 36.6 years; SD, 11.5 years). The median age at diagnosis was 53.5 years (range, 27.4 to 86.2 years; SD, 14.9 years). The mean and median interval until the first metastasis was detected were 3.2 and 1.6 years, respectfully. Twenty of the 34 patients $(59 \%)$ had FCs, and the other 14 patients (41\%) had HCs. Five patients (15\%) presented with their metastasis before the primary thyroid tumor was detected. Four of these five patients had distant metastases (bone $=4$ patients, lung $=1$ patient); all four had FCs. The other patient had a neck lymph 
TABLE 1. Tumor Size and Numbers of Blocks and Slides Submitted

\begin{tabular}{|c|c|c|c|c|c|}
\hline Feature & $\begin{array}{l}\text { Maximum Tumor } \\
\text { Dimension }(\mathrm{cm})\end{array}$ & $\begin{array}{l}\text { Blocks of } \\
\text { Tumor }\end{array}$ & $\begin{array}{l}\text { Slides of } \\
\text { Tumor }\end{array}$ & $\begin{array}{c}\text { Blocks per cm } \\
\text { of Tumor }\end{array}$ & $\begin{array}{l}\text { Slides per } \mathrm{cm} \\
\text { of Tumor }\end{array}$ \\
\hline \multicolumn{6}{|c|}{ Nonmetastatic carcinomas } \\
\hline Mean & 4.9 & 7.1 & 8.5 & 1.2 & 1.6 \\
\hline Median & 4.6 & 6.9 & 8.4 & 1.0 & 1.3 \\
\hline Range (SD) & $2.0-8.1(1.6)$ & $2-45$ & $2-58$ & $0.4-8.7(2.8)$ & $0.6-10.2(3.3)$ \\
\hline \multicolumn{6}{|c|}{ Metastatic carcinomas } \\
\hline Mean & 4.6 & 8.3 & 8.8 & 1.7 & 1.9 \\
\hline Median & 4.2 & 7.5 & 8.0 & 1.7 & 1.8 \\
\hline Range (SD) & $2.4-8.0(1.4)$ & $2-28 \quad(5.3)$ & $2-28$ & $0.6-4.3(0.8)$ & $0.6-6.2 \quad(1.0)$ \\
\hline
\end{tabular}

node metastasis from an HC. Another four patients had their metastasis detected at the time of thyroid surgery, two of which were HCs. Three of these four patients had neck lymph node metastases, and one had a bone metastasis. Of the 25 patients who developed their first metastasis after the thyroid surgery, the mean and median interval until the metastasis was first detected was 4.5 and 3.6 years, respectively (range, 74 days to 13.7 years; SD, 3.8 years).

Twenty-one patients $(62 \%)$ developed their first metastasis in a distant site. The first metastasis was to the bone in 12 patients, lung in 6 patients, liver in 2 patients, and lung and brain in 1 patient. The median age at the time of diagnosis was 48.9 years. The mean and median time periods from the thyroid surgery until the first metastasis was identified was 4.3 and 4.1 years, respectively. Thirteen of the 21 patients $(62 \%)$ had FCs, and the other 14 patients (38\%) had HCs. Seven patients (21\%) developed their first recurrence in the soft tissues of the neck. The median age at diagnosis in this patient group was 47.8 years, and the mean and median time periods from thyroid surgery until their neck softtissue metastasis was identified was 1.7 and 1.6 years, respectively. Six of the seven patients $(86 \%)$ had FCs, and one patient $(14 \%)$ had an HC. Six patients $(18 \%)$ had their initial metastasis to a neck lymph node. The median age at diagnosis in this patient group was 72.8 years, and the mean and median time periods from thyroid surgery until their neck lymph node metastasis was found was 1.3 and 0.43 years, respectively. One patient $(17 \%)$ had FC, and the other five patients (83\%) had HCs.

The mean and median follow-up period of the 38 patients with nonmetastatic FC or HC was 17 and 14 years, respectively (range, 1.1 years to 45 years; $\mathrm{SD}, 7.0$ years). The median age at diagnosis was 41 years (range, 18 to 70 years; SD, 10.5 years).

\section{Pathologic Features}

Table 1 lists tumor size and number of slides and blocks examined. The mean maximum tumor dimension in nonmetastatic and metastatic FCs and HCs was 4.9 and $4.6 \mathrm{~cm}$, respectively. There were no significant differences in the number of blocks or slides examined per patient between the patients who developed metastases and those who did not develop metastases. The carcinomas from seven metastatic and four nonmetastatic specimens were completely embedded. All of these specimens were from the 1980s or 1990s.

The mean, median, and ranges of complete capsular penetration foci, vascular invasion foci, and incomplete capsular penetration foci per neoplasm in the nonmetastatic and metastatic groups were almost identical (Table 2). The median number of complete capsular penetration foci for these two patient groups were 3.4 and 3.0, respectively, and the median number of vascular invasion foci was 2.7 and 3.0, respectively.

Sixty-six percent of the nonmetastatic carcinomas and $62 \%$ of the metastatic carcinomas had two to four foci of complete capsular penetration (Table $3)$. Only five $(13 \%)$ of the nonmetastatic carcinomas and six (17\%) of the metastatic carcinomas had five or more complete capsular penetration foci. The majority of neoplasms in both groups had two to four foci of vascular invasion. One nonmetastatic carcinoma had no capsular penetration (incomplete or complete), but it had two foci of vascular invasion, both of which were within the thick tumor capsule. One nonmetastatic carcinoma also had no vascular invasion, but it had one focus of complete capsular penetration.

Five metastatic carcinomas had one focus of complete capsular penetration, all of which had between two and four foci of vascular invasion. Two metastatic carcinomas, both FCs, had no complete capsular penetration but had one focus and two

TABLE 2. Histologic Parameters of Malignancy in Metastatic and Nonmetastatic Minimally Invasive Follicular Thyroid Carcinoma

\begin{tabular}{lccc}
\hline Parameter & $\begin{array}{c}\text { Complete Capsular } \\
\text { Penetration }\end{array}$ & $\begin{array}{c}\text { Incomplete Capsular } \\
\text { Penetration }\end{array}$ & $\begin{array}{c}\text { Vascular } \\
\text { Invasion }\end{array}$ \\
\hline Nonmetastatic carcinomas $(N=38)$ & $3-16(4.0)$ & $1-7 \quad(2.1)$ \\
Range (SD) & $0-10(2.0)$ & 5.1 & 2.7 \\
Median & 3.4 & 4.0 & 3.1 \\
Mean & 3.4 & & \\
Metastatic carcinomas $(N=34)$ & $2-9 \quad(2.0)$ & $0-6 \quad(1.4)$ \\
Range (SD) & $1-8(1.7)$ & 3.0 & 3.0 \\
Median & 3.0 & 3.6 & 2.8 \\
Mean & 2.9 & & \\
\hline
\end{tabular}


TABLE 3. Distribution of Capsular Penetration and Vascular Invasion Foci in Nonmetastatic and Metastatic

\begin{tabular}{|c|c|c|c|c|c|c|c|c|}
\hline \multirow{2}{*}{ Patient Group } & \multicolumn{4}{|c|}{ Complete Capsular Penetration Foci } & \multicolumn{4}{|c|}{ Vascular Invasion Foci } \\
\hline & 0 & 1 & $2-4$ & $\geq 5$ & 0 & 1 & $2-4$ & $\geq 5$ \\
\hline Nonmetastatic carcinomas & $1(3 \%)$ & $7(18 \%)$ & $25(66 \%)$ & $5(13 \%)$ & $1(3 \%)$ & $15(39 \%)$ & $20(53 \%)$ & $2(5 \%)$ \\
\hline Metastatic carcinomas & $2(6 \%)$ & $5(15 \%)$ & $21(62 \%)$ & $6(17 \%)$ & $1(3 \%)$ & $13(38 \%)$ & $20(60 \%)$ & 0 \\
\hline
\end{tabular}

foci of vascular invasion, respectively. These neoplasms also had three and four foci of incomplete capsular penetration, respectively. Both of these neoplasms were initially diagnosed as adenoma. One HC that produced metastases had no vascular invasion but had four foci of complete capsular penetration. None of the metastatic carcinomas had only incomplete capsular penetration.

\section{Follicular versus Hurthle Cell Morphology among Metastatic Carcinomas}

Of the 34 patients who developed metastases, 20 patients $(59 \%)$ had FC and $14(41 \%)$ had HC morphology (Table 4). The mean and median number of incomplete and complete capsular penetration and vascular invasion foci were almost identical between the two tumor types. The location of the initial metastasis was significantly different between the two groups $(P=.037)$. Of the $20 \mathrm{FCs}, 6$ (30\%) initially developed neck soft-tissue metastases compared with only 1 of $14(7 \%)$ patients with HC. Conversely, only 1 of the 20 FCs (5\%) initially developed neck lymph node metastases compared with 5 of 14 (36\%) patients with HC. A similar majority of patients with FCs (65\%) and HCs (57\%) initially developed distant metastases.

\section{DISCUSSION}

The histologic criteria of minimally invasive FC and HC are well established; complete capsular penetration or vascular invasion identifies a group of neoplasms that have the potential to metastasize or recur $(1-6,8,13-15,17,18,20,21,24-29,33-43)$. Despite the large number of studies that have examined the histologic features associated with metastases or recurrences in minimally invasive FC and HC, the number of patients who develop me- tastases in most of these studies is small. We identified 58 studies, other than case reports, that reported the number of patients with intrathyroidal, minimal (encapsulated) FCs or HCs who developed metastases $(1,2,5,7,9,13-16,20,21,25-28,31-33$, 40-79). Fourteen percent of these studies included no patients who developed metastases, and $42 \%$ of the studies had one to five patients. To our knowledge, there are only three studies, in addition to ours, that have examined more than 30 patients with metastatic carcinoma $(27,31,79)$. Two of these studies are by the same group of authors. None of these studies quantified the number of vascular, incomplete, or complete penetration foci.

We found that there were no significant differences in the number of complete capsular penetration and vascular invasion foci between metastatic and nonmetastatic tumors. The median number of complete capsular penetration or vascular invasion foci in metastatic carcinomas was three. Sixty-two percent of neoplasms had two to four foci of complete capsular penetration, and $60 \%$ had two to four foci of vascular invasion. Almost all of the metastatic FCs and HCs had at least one vascular invasion and complete capsular penetration focus, three had one feature, and none had incomplete capsular penetration only. These values are identical to the mean number of vascular invasion foci of 36 encapsulated FCs reported by Lang et al. $(21,26)$, of which only 2 produced metastases. In one of their studies, $25 \%$ of encapsulated FCs had one vascular invasion focus in 10 tissue blocks, $47 \%$ had two to four vascular invasion foci, and the remaining $39 \%$ had five or more foci (26). Thirty-nine percent of cases had no complete capsular penetration foci, $6 \%$ had one complete capsular penetration focus, $22 \%$ had two to four foci, and $33 \%$ had five or more foci (26). In another study by the

TABLE 4. Metastatic Follicular versus Hurthle Cell Carcinomas

\begin{tabular}{|c|c|c|c|}
\hline Feature & $\begin{array}{c}\text { Follicular } \\
\text { Carcinoma }\end{array}$ & $\begin{array}{l}\text { Hurthle Cell } \\
\text { Carcinoma }\end{array}$ & $P$ Value \\
\hline Number of patients & $20(100 \%)$ & $14(100 \%)$ & \\
\hline Complete capsular penetration foci mean/median & $3.0 / 3.0$ & $2.8 / 2.5$ & 0.9 \\
\hline Vascular invasion foci mean/median & $1.5 / 1.5$ & $1.2 / 1.5$ & 0.9 \\
\hline Incomplete capsular penetration foci mean/median & $3.5 / 3.5$ & $3.7 / 3.8$ & 0.9 \\
\hline Distant metastases & $13(65 \%)$ & $8(57 \%)$ & 0.037 \\
\hline Neck recurrence & $6(30 \%)$ & $1(7 \%)$ & \\
\hline Neck lymph node metastases & $1(5 \%)$ & $5(36 \%)$ & \\
\hline Patient age mean/median & $53.8 / 53.1$ & $58.4 / 53.7$ & 0.7 \\
\hline
\end{tabular}


same group of authors, 53 of 106 (50\%) encapsulated FCs had invaded one to three small blood vessels, and the other 53 (50\%) had invaded a few thick-walled vessels. Complete capsular penetration was rare (21). Another group of authors reported that two minimally invasive FCs had two and seven foci of complete capsular penetration and many sites of vascular invasion, respectively, and in another seven FCs that had no complete capsular penetration, there were at least seven foci of vascular invasion identified in each case (30). Hazard and Kenyon (33) identified vascular space invasion in 2 to $100 \%$ of the countable vessels in 32 encapsulated angioinvasive neoplasms.

There is debate in the literature regarding the prognostic significance of complete capsular penetration versus vascular invasion. Our study suggests that there is no difference in their predictive ability; most metastatic neoplasms had both histologic features, two had vascular space invasion only, and one had complete capsular penetration only. Some authors found that vascular space invasion has stronger association with metastases than capsular invasion $(2,5,21,26,33,37,39,65)$. Other authors have found a compounding effect for the association of these features with metastases $(27,63)$.

Pathologists should be aware that metastases can develop in FCs and HCs that have only a few foci of complete capsular penetration or vascular invasion. A careful search, with the numerous blocks, of all encapsulated follicular or Hurthle cell neoplasms for these histologic features is mandatory.

The median and mean interval between thyroid surgery and when the initial metastasis developed was 1.6 and 3.2 years, respectively. These results confirm the results of other authors that recurrences and metastases by FC and $\mathrm{HC}$ are usually within the first 5 years after surgery, although occasionally they may develop many years after the initial thyroid surgery $(10,11,21,26,27,33,59$, $63-65,74,79,80$ ).

We found no difference in the median number of complete capsular penetration or vascular invasion foci between FC and HC. These results differ from the recent study by Evans et al. (43), who found vein invasion to be significantly more common in FC than in HC. Despite this difference, they were not able to demonstrate a significantly different clinical course in noninvasive FC and HC neoplasms.

We also found that the number of complete capsular penetration and vascular invasion foci were similar among the patients who initially developed local recurrence, neck lymph node, or distant metastases. These results support previous findings that one cannot predict the most likely site of metastasis in a minimally invasive, encapsulated FC or $\mathrm{HC}$ on the basis of the number of vascular space invasion or complete capsular penetration foci (15).
The prognostic significance of a metastasis to these sites may be different. We had insufficient follow-up information to compare the patient's overall survival, initial metastasis location, and the type of postmetastasis adjuvant therapy or additional surgery. Finally, because of the retrospective nature of the study, we cannot be assured that there was no capsular invasion in the nonsampled capsular tissue in those cases with no vascular space invasion and in which the entire capsule was not sampled. The results of this study reflect relationships based on routine sectioning of practice standards over time.

In summary, we found that all of the encapsulated metastatic FCs and HCs had at least one focus of vascular invasion or complete capsular penetration, most had both, and none had capsular invasion only. There was no difference in the number of complete capsular penetration or vascular invasion foci between metastatic and nonmetastatic carcinomas or between metastatic FCs and HCs.

\section{REFERENCES}

1. Woolner LB, Beahrs OH, Black M, McConahey WM, Keating FR Jr. Classification and prognosis of thyroid carcinoma: a study of 885 cases observed in a thirty-year period. Am J Surg 1961;102:354-87.

2. Graham AR. Malignant epithelial tumors of the thyroid with special reference to invasion of blood vessels. Surg Gynecol Obstet 1924;42:781-90.

3. Graham AR. Malignant tumors of the thyroid, epithelial type. Annu Surg 1925;82:30-44.

4. Coller FA. Adenoma and cancer of the thyroid. JAMA 1929; 92:457-62.

5. Warren S. The significance of invasion of blood vessels in adenomas of the thyroid gland. Arch Pathol 1931;11:255-7.

6. Penberton JD. Malignant lesions of the thyroid gland: a review of 774 cases. Surg Gynecol Obstet 1939;417-30.

7. Cole WH, Slaughter DP, Rossiter LJ. Potential dangers of nontoxic nodular goiter. JAMA 1945;127:883-8.

8. Horn RC, Welty RF, Brooks FP, Rhoads JE, Pendergrass EP. Carcinoma of the thyroid. Annu Surg 1947;126:140-55.

9. Hare HF, Salzman FA. Cancer of the thyroid: ten to twenty year follow-up. Am J Roentgenol Radium Ther Nucl Med 1950;63:881-8.

10. Cady B, Sedgwick CE, Meissner WA, Wool MS, Salzman FA, Werber J. Risk factor analysis in differentiated thyroid cancer. Cancer 1979;43:810-20.

11. Franssila KO. Prognosis in thyroid carcinoma. Cancer 1975; 36:1138-46.

12. Frauenhoffer CM, Patchefsky AS, Cobanoglu A. Thyroid carcinoma: a clinical and pathologic study of 125 cases. Cancer 1979;43:2414-21.

13. Arganini M, Behar R, Wu TC, Straus F, McCormick M, DeGroot LJ, et al. Hurthle cell tumors: a twenty-five-year experience. Surgery 1986;100:1108-15.

14. Bronner MP, Livolsi VA. Oxyphilic (Askanazy/Hurthle cell) tumors of the thyroid: microscopic features predict biologic behavior. Surg Pathol 1988;1:137-49.

15. Carcangiu ML, Bianchi S, Savino D, Voynick IM, Rosai J. Follicular Hurthle cell tumors of the thyroid gland. Cancer 1991;68:1944-53.

16. Chen HY, Benjamin LB, Chen MF. Hurthle cell tumor. Int 
Surg 1996;81:168-70.

17. Flint A, Lloyd RV. Hurthle-cell neoplasms of the thyroid gland. Pathol Annu 1990;25(Pt 1):37-52.

18. Frazell EL, Duffy BJ. Hurthle cell cancer of the thyroid: a review of 40 cases. Cancer 1951;4:952-9.

19. Galera-Davidson H, Bibbo M, Bartels PH, Dytch HE, Puls JH, Wied GL. Correlation between automated DNA ploidy measurements of Hurthle-cell tumors and their histopathologic and clinical features. Anal Quant Cytol Histol 1986;8:158-67.

20. Horn RC. Hurthle cell tumors of the thyroid. Cancer 1954;7: 234-44.

21. Lang W, Choritz H, Hundeshagen H. Risk factors in follicular thyroid carcinomas: a retrospective follow-up study covering a 14 year period with emphasis on morphological findings. Am J Surg Pathol 1986;10:246-55.

22. McLeod MK, Thompson NW, Hudson JL, Gaglio JA, Lloyd $\mathrm{RV}$, Harness JK, et al. Flow cytometric measurements of nuclear DNA and ploidy analysis in Hurthle cell neoplasms of the thyroid. Arch Surg 1988;123:849-54.

23. Rosai J, Carcangiu ML. Pathology of thyroid tumors: some recent and old questions. Hum Pathol 1984;15:1008-12.

24. Woolner LB. Thyroid carcinoma: pathologic classification with data on prognosis. Semin Nucl Med 1971;1:482-502.

25. Franssila KO. Value of histologic classification of thyroid cancer. Acta Pathol Microbiol Scand 1971; 225A(Suppl):1-76.

26. Lang W, Georgii A, Stauch G, Kienzle E. The differentiation of atypical adenoma and encapsulated follicular carcinomas in the thyroid gland. Virchows Arch Pathol Anat Histopathol 1980A;385:125-41.

27. Kahn NF, Perzin KH. Follicular carcinoma of the thyroid: an evaluation of the histologic criteria used for diagnosis. Pathol Annu 1983;18(Pt 1):221-53.

28. Evans HL. Follicular neoplasms of the thyroid: a study of 44 cases followed for a minimum of 10 years, with emphasis on differential diagnosis. Cancer 1984;54:535-40.

29. Franssila KO, Ackerman LJ, Brown CL, Hedinger CE. Follicular carcinoma. Semin Diagn Pathol 1985;2:101-22.

30. Yamashina M. Follicular neoplasms of the thyroid: total circumferential evaluation of the fibrous capsule. Am J Surg Pathol 1992;16:392-400.

31. Segal K, Arad A, Lubin E, Shpitzer T, Hadar T, Feinmesser R. Follicular carcinoma of the thyroid. Head Neck 1994;16: 533-8.

32. Schmid KW, Totsch M, Ofner D, Bocker W, Ladurner D. Minimally invasive follicular thyroid carcinoma: a clinicopathological study. Curr Top Pathol 1997;91:37-43.

33. Hazard B, Kenyon R. Encapsulated angioinvasive carcinoma (angioinvasive adenoma) of the thyroid gland. Am J Clin Pathol 1954;24:755-66.

34. Carcangiu ML, Sibley RK, Rosai J. Clear cell change in primary thyroid tumors: a study of 38 cases. Am J Surg Pathol 1985;9:705-22.

35. Clute HM, Smith LW. Cancer of the thyroid gland. Arch Surg 1929;18:1-19.

36. Lahey FW, Hare HF, Warren S. Carcinoma of the thyroid. Annu Surg 1940;112:977-1005.

37. Warren S, Meissner WA. Tumors of the thyroid gland. In: Atlas of tumor pathology (Sect. IV, Fasc. 13). Washington, DC: Armed Forces Institute of Pathology; 1994.

38. Hazard B, Kenyon R. Atypical adenoma of the thyroid. Arch Pathol 1954;58:554-63.

39. Warren S. Invasion of blood vessels in thyroid cancer. Am J Clin Pathol 1956;26:64-5.

40. Horn RC. Problems in the pathologic diagnosis of carcinoma of the thyroid. Arch Pathol 1960;69:481-92.

41. Crile G Jr, Hawk WA. Carcinomas of the thyroid. Cleve Clin Q 1971;38:97-104.

42. Tollefsen HR, Shah JP, Huvos AG. Follicular carcinoma of the thyroid. Am J Surg 1973;126:523-8.
43. Evans HL, Vassilopoulou-Sellin R. Follicular and Hurthle cell carcinomas of the thyroid: a comparative study. Am J Surg Pathol 1998;22:1512-20.

44. McKenzie AD. The natural history of thyroid cancer. Arch Surg 1971;102:274-7.

45. Iida F. Surgical significance of capsule invasion of adenoma of the thyroid. Surg Gynecol Obstet 1977;144:710-2.

46. Silverberg SG, Vidone RA. Adenoma and carcinoma of the thyroid. Cancer 1966;19:1052-62.

47. Gosain AK, Clark OH. Hurthle cell neoplasms. Arch Surg 1984;119:515-9.

48. Saull SC, Kimmelman CP. Hurthle cell tumors of the thyroid gland. Otolaryngol Head Neck Surg 1985;93:58-62.

49. Heppe H, Armin A, Calandra DB, Lawrence AM, Paloyan E. Hurthle cell tumors of the thyroid gland. Surgery 1985;98: 1162-5.

50. Fukunaga M, Shinozaki N, Endo Y, Ushigome S. Atypical adenoma of the thyroid: a clinicopathologic and flow cytometric DNA study in comparison with other follicular neoplasms. Acta Pathol Jpn 1992;42:632-8.

51. Lin KD, Lin JD, Huang MJ, Huang HS, Jeng LB, Chao TC, et al. Clinical presentations and predictive variables of thyroid microcarcinoma with distant metastasis. Int Surg 1997;82: $378-81$.

52. Farahati J, Bucsky P, Parlowsky T, Mader U, Reiners C. Characteristics of differentiated thyroid carcinoma in children and adolescents with respect to age, gender, and histology. Cancer 1997;80:2156-62.

53. Bondeson L, Bondeson AG, Ljungberg O, Tibblin S. Oxyphil tumors of the thyroid: follow-up of 42 surgical cases. Annu Surg 1981;194:677-80.

54. Gardner LW. Hurthle cell tumors of the thyroid. Arch Pathol 1955;59:372-81.

55. Miller RH, Estrada R, Sneed WF, Mace ML. Hurthle cell tumors of the thyroid gland. Laryngoscope 1983;93:884-8.

56. Caplan RH, Abellera RM, Kisken WA. Hurthle cell tumors of the thyroid gland: a clinicopathologic review and long-term follow-up. JAMA 1984;251:3114-7.

57. Akslen LA, Myking AO. Differentiated thyroid carcinomas: the relevance of various pathological features for tumor classification and prediction of tumor progress. Virchows Arch [A] Pathol Anat Histopathol 1992;421:17-23.

58. Zimmermann LM, Wagner DH, Perlmutter HM, Amromin GD. Benign and malignant epithelial tumors of the thyroid gland. Arch Surg 1950;60:1183-98.

59. Chesky VE, Dreese WC, Hellwig CA. Hurthle cell tumors of the thyroid gland: report on 25 cases. J Clin Endocrinol Metab 1951;11:1535-49.

60. Blum M, Feiner HD, Worth MH, King LW. Clinical implications of the rare thyroid carcinoma which is indistinguishable from a follicular adenoma. Am J Med Sci 1978;276:99104.

61. Crile G Jr, Pontius KI, Hawk WA. Factors influencing the survival of patients with follicular carcinoma of the thyroid gland. Surg Gynecol Obstet 1985;160:409-13.

62. Donohue JH, Goldfien SD, Miller TR, Abele JS, Clark OH. Do the prognoses of papillary and follicular thyroid carcinomas differ? Am J Surg 1984;148:168-73.

63. Schroder S, Pfannschmidt N, Dralle H, Arps H, Bocker W. The encapsulated follicular carcinoma of the thyroid: a clinicopathologic study of 35 cases. Virchows Arch [A] Pathol Anat Histopathol 1984;402:259-73.

64. DeGroot LJ, Kaplan EL, Shukla MS, Salti G, Straus FH. Morbidity and mortality in follicular thyroid cancer. J Clin Endocrinol Metab 1995;80:2946-53.

65. Jorda M, Gonzalez-Campora R, Herrero-Zapatero A, Otal C, Galera H. Prognostic factors in follicular carcinoma of the thyroid. Arch Pathol Lab Med 1993;117:631-5.

66. Emerick GT, Duh QY, Siperstein AE, Burrow GN, Clark OH. 
Diagnosis, treatment, and outcome of follicular thyroid carcinoma [see comments]. Cancer 1993;72:3287-95.

67. Hirabayashi RN, Lindsay S. Carcinomas of the thyroid gland: a statistical study of 390 patients. J Endocrinol Metab 1961; 21:1596-610.

68. Har-El G, Hadar T, Segal K, Levy R, Sidi J. Hurthle cell carcinoma of the thyroid gland: a tumor of moderate malignancy. Cancer 1986;57:1613-7.

69. Samaan NA, Maheshwari YK, Nader S, Hill CSJ, Schultz PN, Haynie TP, et al. Impact of therapy for differentiated carcinoma of the thyroid: an analysis of 706 cases. J Clin Endocrinol Metab 1983;56:1131-8.

70. Young RL, Mazzaferri EL, Rahe AJ, Dorfman SG. Pure follicular thyroid carcinoma: impact of therapy in 214 patients. J Nucl Med 1980;21:733-7.

71. Johannessen JV, Sobrinho-Simoes M. Follicular carcinoma of the human thyroid gland: an ultrastructural study with emphasis on scanning electron microscopy. Diag Histopathol 1982;5:113-27.

72. Gonzalez-Campora R, Herrero-Zapatero A, Lerma E, Sanchez F, Galera H. Hurthle cell and mitochondrion-rich cell tumors: a clinicopathologic study. Cancer 1986;57:115463.

73. Selzer G, Kahn LB, Albertyn L. Primary malignant tumors of the thyroid gland: a clinicopathologic study of 254 cases.
Cancer 1977;40:1501-10.

74. Cady B, Sedgwick CE, Meissner WA, Bookwalter JR, Romagosa V, Werber J. Changing clinical, pathologic, therapeutic, and survival patterns in differentiated thyroid carcinoma. Annu Surg 1976;184:541-53.

75. Gundry SR, Burney RE, Thompson NW, Lloyd RV. Total thyroidectomy for Hurthle cell neoplasm of the thyroid. Arch Surg 1983;118:529-32.

76. Thompson NW, Dunn EL, Batsakis JG, Nishiyama RH. Hurthle cell lesions of the thyroid gland. Surg Gynecol Obstet 1974;139:555-60.

77. Watson RG, Brennan MD, Goellner JR, van Heerden JA, McConahey WM, Taylor WF. Invasive Hurthle cell carcinoma of the thyroid: natural history and management. Mayo Clin Proc 1984;59:851-5.

78. Lin JD, Huang HS, Chen SC, Chao TC. Factors that predict metastasis of papillary and follicular thyroid cancers in Taiwan. Otolaryngol Head Neck Surg 1997;116:475-82.

79. Segal K, Raveh E, Lubin E, Abraham A, Shvero J, Feinmesser R. Well-differentiated thyroid carcinoma. Am J Otolaryngol 1996;17:401-6.

80. Shaha AR, Shah JP, Loree TR. Patterns of nodal and distant metastasis based on histologic varieties in differentiated carcinoma of the thyroid. Am J Surg 1996;172:692-4. 